\title{
Analisa Faktor yang Mempengaruhi Tingkat Fertilitas (TFR) di Provinsi Maluku (Analisa Lanjutan Hasil SKAP 2019)
}

\section{Analysis of Factors Affecting Fertility Rate (TFR) in Maluku Province (Continued Analysis of 2019 SKAP Results)}

\section{Marfin Lawalata*1,3, Jino Tehusalawane ${ }^{2}$, Misco Tamaela ${ }^{3}$, Marlon S. Noya van Delzen $^{1,4}$ \& Felecia P. Adam ${ }^{1,3}$}

\author{
${ }^{1}$ Pusat Studi Kependudukan dan Kesejahteraan Sosial (PSKKS), Universitas Pattimura \\ ${ }^{2}$ Widyaiswara, BKKBN Kantor Perwakilan Provinsi Maluku \\ 3Jurusan Sosial Ekonomi Pertanian, Fakultas Pertanian \\ ${ }^{4}$ Jurusan Matematika, Fakultas Matematika dan Ilmu Pengetahuan Alam \\ Universitas Pattimura, Jln. Ir. M. Putuhena, Kampus Poka, Ambon, 97233
}

Diterima: 28 Juli 2021; Direview: 28 Juli 2021; Disetujui: 25 November 2021

\begin{abstract}
Abstrak
Penelitian ini bertujuan untuk mengetahui determinan faktor penyebab tingginya Tingkat Fertilitas (TFR) yang berpengaruh terhadap jumlah anak lahir hidup. Data yang digunakan adalah data SKAP tahun 2019, dengan responden adalah wanita usia subur umur 15-49 tahun. Dengan model yang digunakan adalah analisis regresi logistik biner. Hasil peneltian menunjukan bahwa, 12 variabel memiliki hubungan bermakna terhadap anak lahir hidup. Kematian anak merupakan variabel paling dominan berpengruh nyata terhadap jumlah anak lahir hidup. Rekomendasi yang dapat diberikan dari hasil penelitian ini adalah Meningkatkan pengawasan Dinas Kesehatan terkait penguatan kapasitas kelembagaan lewat penyuluhan/komunikasi, Informasi, dan Edukasi lewat program penundaan usia kawin, umur melahirkan pertama, usia pertama hubungan dan edukasi tentang sex usia dini lewat pendidiakn konseling kesehatan reproduksi remaja dalam rangka meningkatkan pengetahuan, sikap, dan perilaku keluarga dan masyarakat untuk mewujudkan keluarga yang berkualitas.

Kata Kunci: Faktor Determinan; Tingkat Fertilitas; Faktor Demografi; Sosial Ekonomi.
\end{abstract}

\begin{abstract}
The purpose of this study was to determine the determinants of the factors causing the high Fertility Rate (TFR), rs that affect the number of children born alive. The data used is SKAP data in 2019, with a respondent of women of childbearing age aged 15-49 years. With the model used is binary logistic regression analysis. The results showed that 12 variables had a significant relationship with live births. Child mortality is the most dominant variable that has a significant effect on the number of children born alive, Recommendations that can be given from the results of this study are to increase the supervision of the Health Office related to strengthening institutional capacity through counseling / communication, information, and education through postponement of marriage age and first birth age programs. first age relationship and education about early childhood sex through adolescent reproductive health counseling in order to increase knowledge, attitudes, and behavior of families and communities to create a quality family.

Keywords: Determinant Factors, Fertility Rate, Demographic, Socio-Economic.
\end{abstract}

How to Cite: Lawalata, M., Tehusalawane, J., Tamaela, M., Noya van Delzen, M.S., \& Adam, F.P., (2022). Analisa Faktor Yang Mempengaruhi Tingkat Fertilitas di Provinsi Maluku (Analisa Lanjutan Hasil SKAP 2019). Perspektif, 11 (1): 318-332

$\begin{array}{lr}* \text { Corresponding author : } & \text { ISSN 2085-0328 (Print) } \\ \text { E-mail : marfinlawalata@gmail.com } & \text { ISSN 2541-5913 (online) }\end{array}$




\section{PENDAHULUAN}

Masalah pengendalian penduduk adalah masalah krusial bagi negara berkembang seperti di Indonesia yang harus segera ditangani. dengan laju pertumbuhan penduduk yang pesat serta ditandai dengan jumah penduduk yang tinggi, yang akan berdampak terhadap kemungkinan terjadiya "population boom" (The Population Explotion, Ehrlich dalam Suartha, 2016). Jumlah penduduk di Indonesia berdasarkan data terakhir BPS, mencatat pada tahun 2015 sebesar 238.518.000 jiwa di Indonesia diproyeksikan pada 2020 akan meningkat sebesar $13,6 \%$ atau sebanyak 271.066 .000 jiwa.

Penduduk adalah subjek serta pelaku dalam sasaran pembangunan, namun jumlah penduduk yang pesat juga dapat menghambat keberhasilan dalam mencapai pembangunan. Hal ini dikarenakan besarnya jumlah penduduk yang tidak berbanding lurus dengan kualitas penduduknya, jumlah penduduk yang tinggi dapat mengakibatkan rendahnya kehidupan layak, serta daya pemerintah dalam menanggulanginya. Salah satu faktor yang mempengaruhi laju pertumbuhan penduduk yang besar adalah fertilitas atau kelahiran, adanya hubungan antara jumlah kelahiran atau fertilitas linear terhadap pertumbuhan penduduk yang pesat pula (Sinaga, 2017).

Salah satu faktor yang mempengaruhi laju pertumbuhan penduduk yang besar adalah fertilitas atau kelahiran, adanya hubungan antara jumlah kelahiran atau fertilitas linear terhadap pertumbuhan penduduk yang pesat pula (Sinaga, 2017). Untuk menjawab hal ini, program kependudukan dan keluarga berencana diharapkan mampu menjadi salah satu program investasi pembangunan jangka panjang yang diharapkan mampu menjadi landasan membangun kuantitas dan kulitas sumber daya manusia di masa mendatang.

Membatasi jumlah kelahiran tidak mudah dilakukan, mengingat jumlah pertumbuhan penduduk yang semakin bertambah. Hal ini karena dalam sebuah perkawinan, anggapan dengan mempunyai anak adalah keinginan setiap inividu yang tidak dapat dipaksakan. Karena Anak adalah anugerah yang tidak ternilai dan keinginan setiap keluarga, sehingga tidak heran jika ada anggapan bahwa banyak anak banyak rezeki (Najib, 2019). Ternyata anggapan tersebut pada saat ini ditepis bahwa mempunyai anak yang banyak tidak menjamin banyaknya rezeki yang didapat, dilihat dari segi ekonomi banyaknya anak akan mempengaruhi berapa banyak biaya yang akan dikeluarkan untuk membesarkan dan merawat anak pada masa yang akan datang dengan biaya hidup dan pendidikan yang terlampau mahal.

Berdasarkan data SDKI (Survei Demografi dan Kesehatan Indonesia), TFR nasional mengalami penurunan dari 2,6 anak per wanita usia subur pada tahun 2012 menjadi 2,4 anak per wanita usia subur pada tahun 2017, sedangkan berdasarkan data SKAP, tahun 2019 TFR nasional mencapai 2,45 anak per wanita usia subur diharapkan angkanya akan tetap dipertahankan dan konstan pada 5 tahun mendatang dengan asumsi semakin tingkat kelahiran pada perempuan usia reproduktif maka resiko kematian bayi dan ibu dapat ditekan. Penurunan angka TFR Nasional erat kaitan dengan keberhasilan program KB meningkatnya prevalensi pemakaian kontrasepsi. Angka prevalensi ber-KB berhasil ditingkatkan dari 61,9 persen pada tahun 2012 menjadi 63,6 persen pada SDKI 2017. Namun, di Provinsi Maluku sendiri, angka TFR masih jauh sangat tinggi bila dibandingkan angka nasional dan provinsi lain di Indonesia yaitu sebesar 3,3 anak per wanita usia subur. Sementara pencapaian prevalensi ini di tingkat provinsi lain juga cukup beragam di Provinsi Maluku sendiri berkisar 46,9 persen prevalensi kontrasepsi pada wanita kawin 1549 tahun.

Penelitian ini bertujuan untuk menganalisa determinan faktor fertilitas di Provinsi Maluku. Untuk mereduksi angka kelahiran pada wanita usia produktif, maka ada beberapa hal yang dapat dilakukan yaitu dengan memperhatikan faktor-faktor apa yang mempengaruhi lajunya TFR yaitu menurut Mantra dalam Rakhmatullah (2015) pengendalian fertilitas merupakan salah satu cara untuk mengendalikan jumlah penduduk. Terdapat sejumlah faktor yang dapat mempengaruhi tingkat fertilitas yaitu, (1) faktor demografi dan (2) Faktor non demografi. Faktor-faktor tersebut dapat berpengaruh langsung ataupun tidak langsung terhadap fertilitas. 
Marfin Lawalata, Jino Tehusalawane, Misco Tamaela, Marlon S. Noya van Delzen \& Felecia P. Adam, Analisa Faktor Yang Mempengaruhi Tingkat Fertilitas di Provinsi Maluku (Analisa Lanjutan Hasil SKAP 2019)

\section{METODE PENELITIAN}

Penelitian ini merupakan penelitian kuantitatif yang bersifat analitik korelatif. Data yang digunakan dalam penelitian ini adalah data sekunder yang bersumber dari data hasil Survei Kinerja Akuntabilitas Program KKBPK Tahun 2019. Survei ini dilaksanakan oleh Badan Kependudukan dan Keluarga Berencana Nasional (BKKBN). Dengan responden Wanita Usia Subur (WUS) berumur 15-49 yaitu sebanyak 1559 responden yang tersebar di provinsi Maluku. Setelah dilakukan pemeriksaan terhadap hasil wawancara (kuesioner) terdapat 1 responden yang tidak bersedia diwawancarai. Sehingga jumlah kuesioner yang dapat dilakukan untuk analisis data adalah sebanyak 1558 kuesioner.

Kriteria sampel yaitu pernah melahirkan dan berdomisili di Provinsi Maluku. Cara pengambilan sampel dengan menggunakan total sampling yaitu semua WUS dari Provinsi Maluku yang berpartisipasi dalam SKAP 2019 dijadikan sebagai sampel penelitian. Analisis data yang digunakan adalah Analisis univariat, Analisis bivariate Analisis bivariat/uji statistik, dan analisis multivariate yang akan digunakan adalah analisis regresi logistik karena variabel terikatnya berupa data kategorik.

Data Hasil SKAP KKBPK 2019, diambil variabel yang sesuai dengan tujuan penelitian dan diolah menggunakan SPSS Ver. 23. yaitu Analisis Regresi Logistik Biner. Tahap selanjutnya setelah pengolahan data selesai, maka yang dilakukan adalah analisis dan interpretasi data. Penelitian ini menggunakan analisis deskriptif. Analisis kuantitatif yaitu Analisis Regresi Logistik Biner untuk menjawab tujuan permasalahan penelitian agar dapat dijelaskan dengan mudah dan ringkas mengenai determinan faktor-faktor penyebab tingginya TFR Di Provinsi Maluku. Tidak hanya hasil analisis kuantitatif yang dinterpretasikan tetapi untuk mendapatkan jawaban yang komprehensif maka dilakukan juga analisis deskriptif kuantitatif melalui studi pustkan/literartur untuk mengkaji faktor sosial/ekonomi, budaya dan geografis yang menjadi penyebab tingginya angka fertlitas di Maluku.

\section{HASIL DAN PEMBAHASAN \\ Distribusi Frekuensi Faktor Penentu Fertilitas}

Distribusi frekuensi faktor penentu fertilitas jumlah anak lahir hidup. Berdasarkan gambar 1 dapat dilihat bahwa sebanyak $30,04 \%$ wanita belum memiliki anak, sedangkan sebanyak $32,67 \%$ wanita memiliki 1-2 anak, dan 37,29\% memiliki lebih dari 2 anak. Karakteristik responden wanita subur dari usia 15 sampai dengan usia 49 tahun yang memiliki jumlah anak 0 sampai dengan lebih dari 2 anak menjadi tolak ukur preferensi tingkat kelahiran anak lahir hidup atau TFR di Provinsi Maluku.

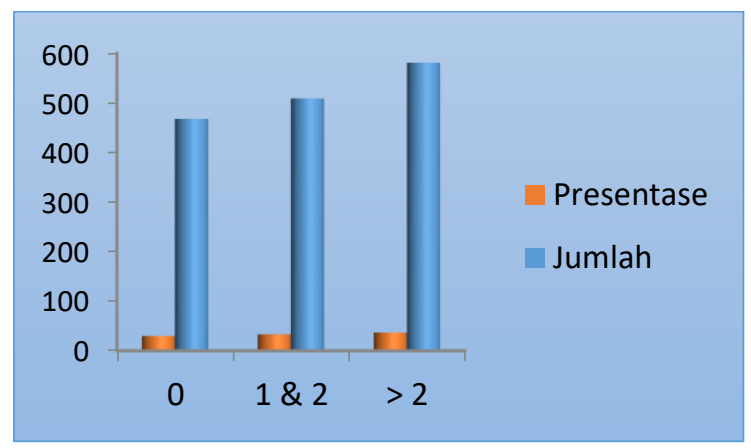

Gambar 1. Distribusi Responden (Wanita Usia Subur 15-49 tahun) Menurut Jumlah Anak Lahir Hidup, SKAP 2019

Berdasarkan wilayah tempat tinggal, sebagian besar responden wanita bertempat tinggal di wilayah pedesaan diperlihatkan bahwa responden wanita terbanyak bertempat tinggal di pedesaan, sebesar 66,30\%. Sedangkan sisanya 33,70\% wanita bertempat tinggla di perkotaan. (gambar 2).

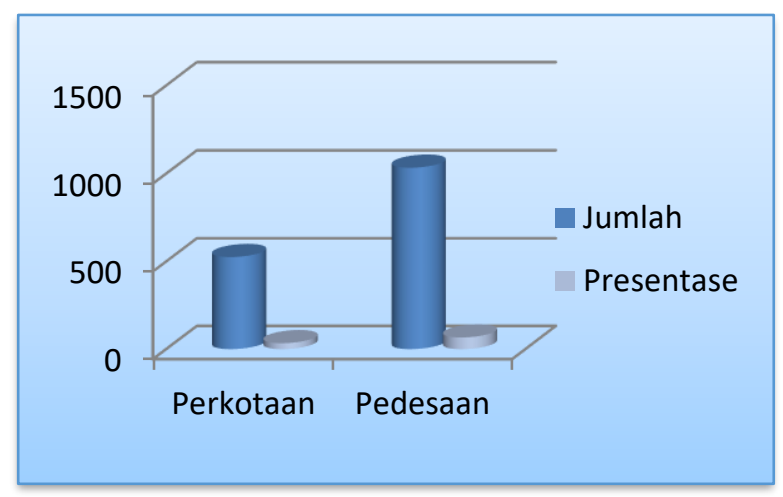

Gambar 2. Distribusi Responden Menurut tempat tinggal, SKAP 2019 
Gambar 3 menunjukkan kelompok umur dengan responden terbanyak yaitu pada interval umur 35-39 tahun, dengan persentase sebesar 17,07\%. Sedangkan kelompok umur tersedikit terdapat pada kelompok umur 4549 tahun, dengan persentase sebesar 11,05\%.

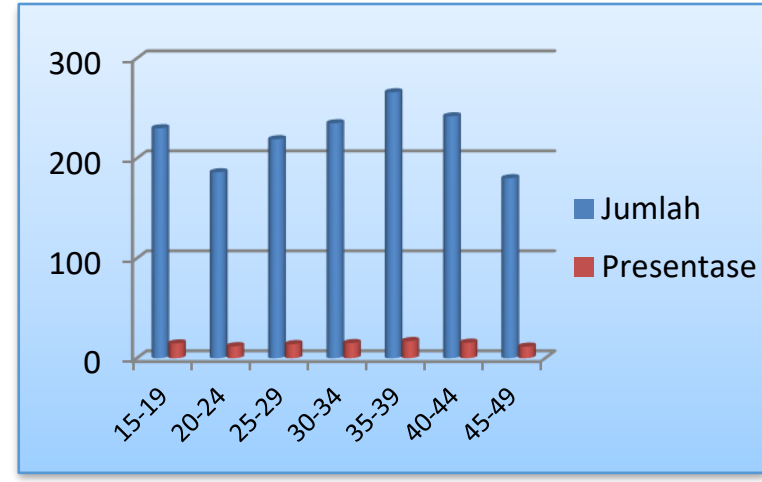

Gambar 3. Distribusi Responden Menurut kelompok usia, SKAP 2019

Sedangkan gambar 3 memberikan informasi lebih lanjut mengenai jenis pekerjaan dari 1558 responden, dimana $56,48 \%$ dari total responden tidak bekerja atau berstatus sebagai ibu RT. Selain itu juga terdapat responden yang belum bekerja atau berstatus sebagai pelajar sebesar $21,95 \%$.

Sedangkan jika dilihat berdasarkan responden yang telah bekerja maka presentase terbesar terdapat pada responden yang bekerja sebagai PNS/ TNI/ POLRI/BUMN/ Lainnya, yaitu sebesar 6,80 \%. Sedangkan berdasarkan tingkat kesejahteraan 56,42 \% wanita berada di tingkat menengah. Hal ini menggambarkan bahwa responden wanita berada pada tingkat kesejehteraan menengah.

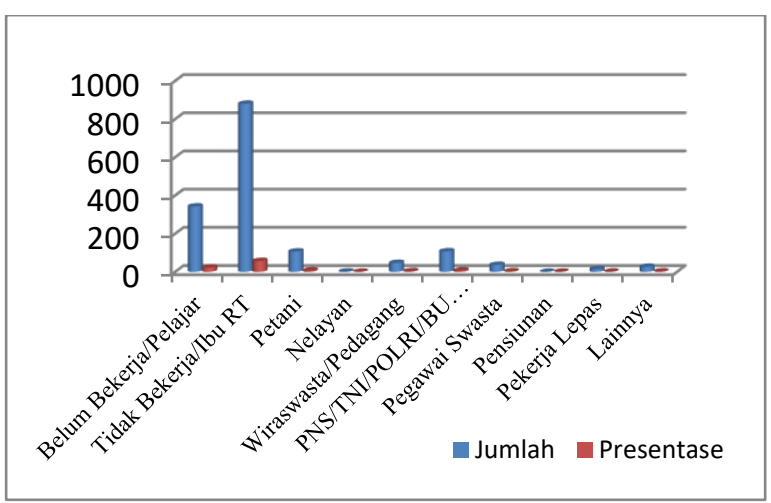

Gambar 4. Distribusi Menurut Status bekerja SKAP 2019

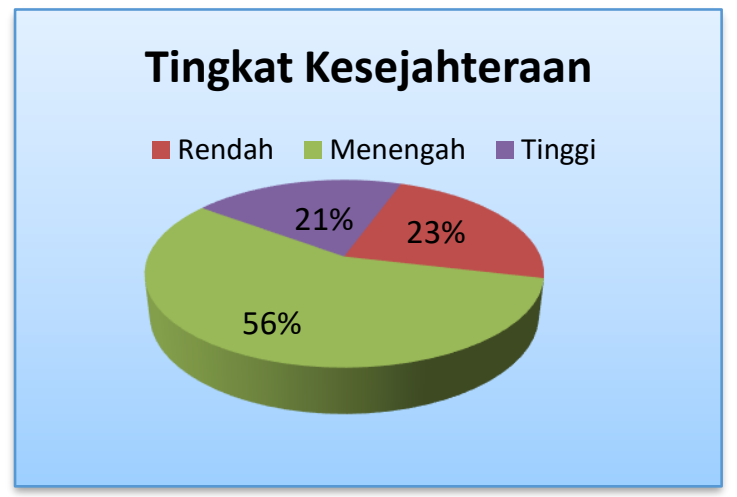

Gambar 5. Distribusi Menurut tingkat kesejahteraan, SKAP 2019

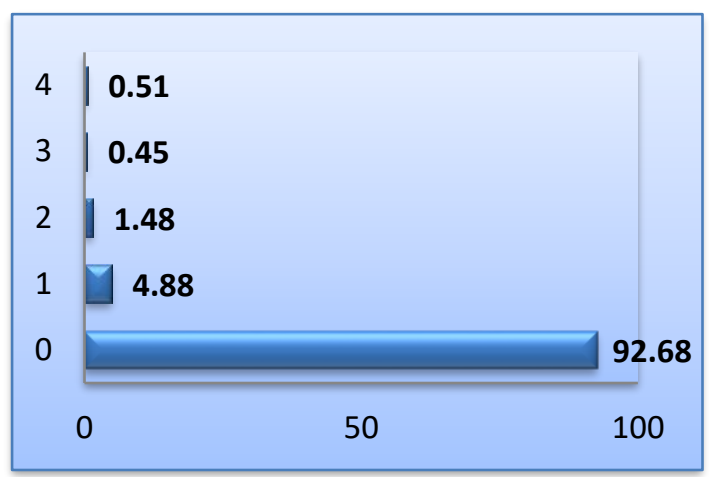

Gambar 6. Distribusi Responden Menurut Jumlah Kematian Anak, SKAP 2019

Gambar 6, dapat dilihat bahwa hampir $93 \%$ wanita subur tidak pernah mengalami kematian anak. Sisanya hampir $5 \%$ wanita kehilangan anak sedikitnya 1 orang, hampir 2 orang kehilangan anak sedikitnya 2 orang. dan kurang dari $1 \%$ kehilangan anak sebanyak 3 sampai dengan 4 orang anak. Dan gambar 6 menunjukan bahwa, sebagian besar wanita menginginkan anak 2 anak atau kurang dari itu. Sisanya hampir $48 \%$ menginginkan lebih dari 2 anak.

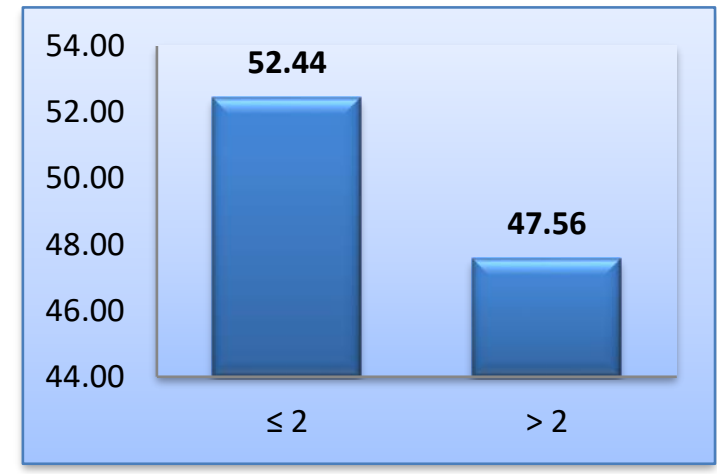

Gambar 7. Distribusi Responden Menurut Jumlah Anak yang Diinginkan, SKAP 2019 
Marfin Lawalata, Jino Tehusalawane, Misco Tamaela, Marlon S. Noya van Delzen \& Felecia P. Adam, Analisa Faktor Yang Mempengaruhi Tingkat Fertilitas di Provinsi Maluku (Analisa Lanjutan Hasil SKAP 2019)

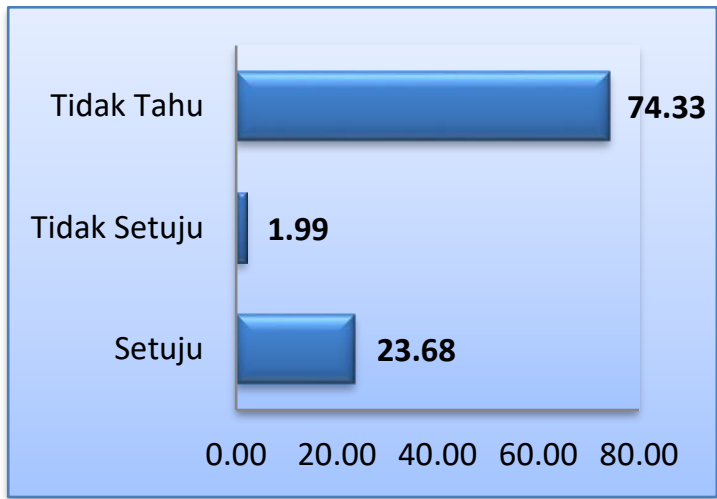

Gambar 8. Distribusi Responden Menurut Keputusan ber-KB, SKAP 2019

Berdasarkan gambar 8 dapat dilihat $23,86 \%$ suami responden setuju dengan $\mathrm{KB}$, sedangkan 1,99\% suami responden tidak setuju dengan KB. Sedangkan berdasarkan pengetahuan tentang $\mathrm{KB}$ dari sumber media lainnya, sebagian besar responden menerima informasi mengenai $\mathrm{KB}$ melalui $\mathrm{TV}$, yaitu sebesar 51,54\%. Sedangkan sisanya diikuti oleh Majalah sebesar 21,69\%; Internet sebesar 21,12\%; dan Radio sebesar 2,18\%.

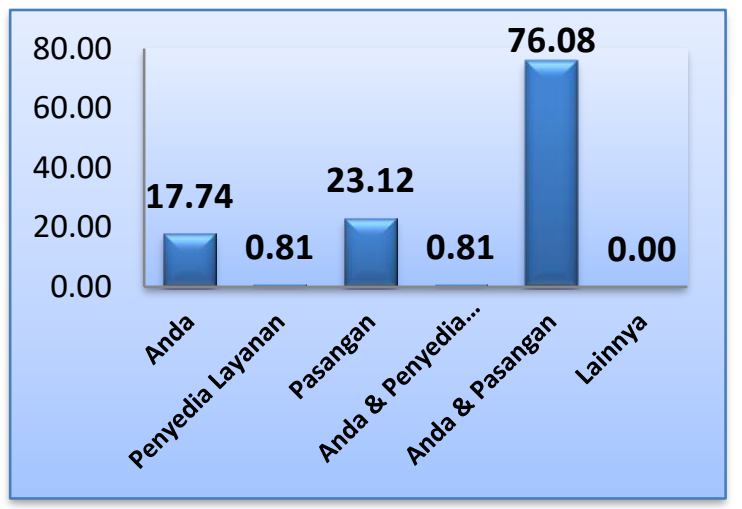

Gambar 9. Distribusi Pendapat Suami Terhadap KB, SKAP 2019

Berdasarkan gambar 9. lebih dari 76\% responden wanita mengaku menggunakan $\mathrm{KB}$ secara bersama-sama dengan pasanganya. Lebih dari $23 \%$ hanya pasangan yang menyetujui penggunaan KB. Dan sisanya hanya wanita sendiri yang memilih untuk mengambil keputusan untuk ber-KB tanpa persetujuan dari pasangannya. Sebagian besar responden pada saat melakukan wawancara telah menikah, yaitu sebesar 71,37\%. Sedangkan responden yang hingga saat melakukan wawancara belum menikah sebesar 24,52\%. Jika dilihat berdasarkan umur pada saat melakukan hubungan sex pertama pada gambar 10 sebanyak, 30,30\% responden melakukannya di umur 20-24 tahun. Kemudian responden yang melakukan hubungan sex di bawah 15 tahun sebesar $1,67 \%$ dan responden yang mengaku belum pernah melakukan hubungan sex sebesar 18,89\%. Jumlah responden terbesar untuk umur kawin pertama berada pada umur 20-24 tahun, yaitu sebesar 33,89\%. Kemudian dilanjutkan pada interval umur 15-19 tahun, yang sebesar 24,84\%. Sedangkan untuk responden yang menikah untuk pertama kalinya di atas 25 tahun hanya terdapat $16,75 \%$.

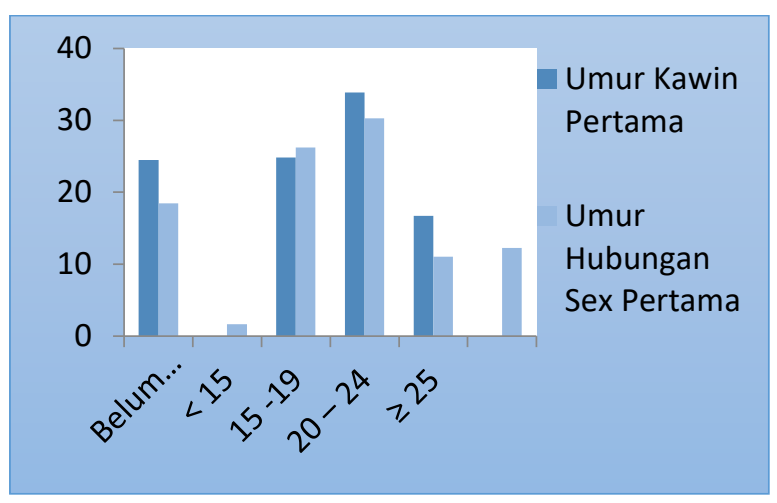

Gambar 10. Distribusi umur responden pertama kali melakukan hubungan seksual dan umur kawin pertama, SKAP 2019

Berdasarkan status pernikahan pada gambar 11, sebagian besar responden pada saat melakukan wawancara telah menikah, yaitu sebesar 71,37\%. Sedangkan responden yang hingga saat melakukan wawancara belum menikah sebesar $24,52 \%$.

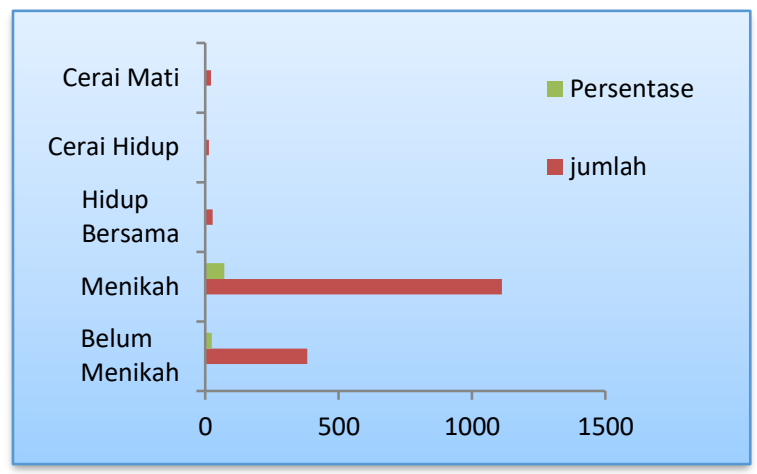

Gambar 11. Distribusi Responden menurut faktor langsung berdasarkan status pernikahan, SKAP 2019 
Sedangkan distribusi responden berdasarkan umur pertama kali melahirkan (gambar 12) adalah hampir setengah responden belum pernah melahirkan hingga saat dilakukan wawancara, yaitu sebesar $44,16 \%$. Sedangkan responden yang pernah melahirkan, jumlah responden melahirkan pertama terbanyak pada umur 20-24 tahun sebesar 27,21\%.

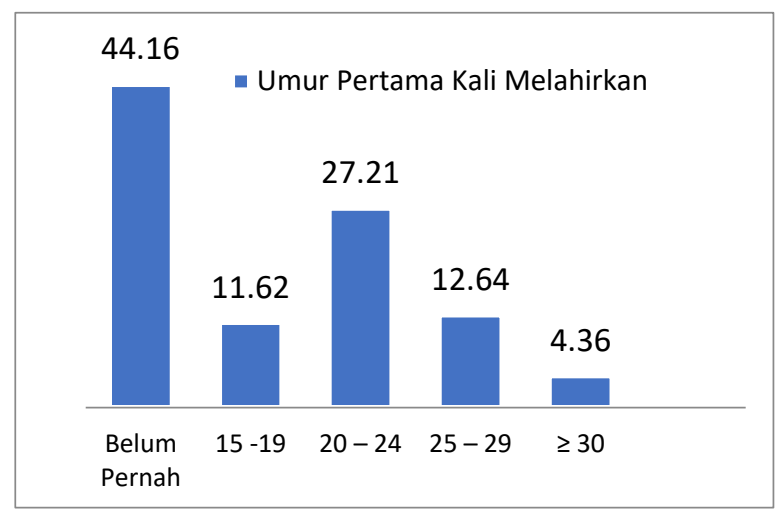

Gambar 12. Distribusi responden berdasarkan umur pertama kali melahirkan, SKAP 2019

Gambar 13. memberi informasi untuk responden yang tidak menggunakan alat $\mathrm{KB}$ hingga pada saat dilakukan wawancara hampir mencapai tiga per empat dari total responden, yaitu sebesar $74,13 \%$ dan sisanya 25,87\% sedang menggunakan alat $\mathrm{KB}$ pada saat dilakukan wawancara.

Gambar 13. Distribusi Responden Menurut Faktor Langsung, berdasarkan pemakaian KB, Infertilitas dan ASI eksklusif, SKAP 2019

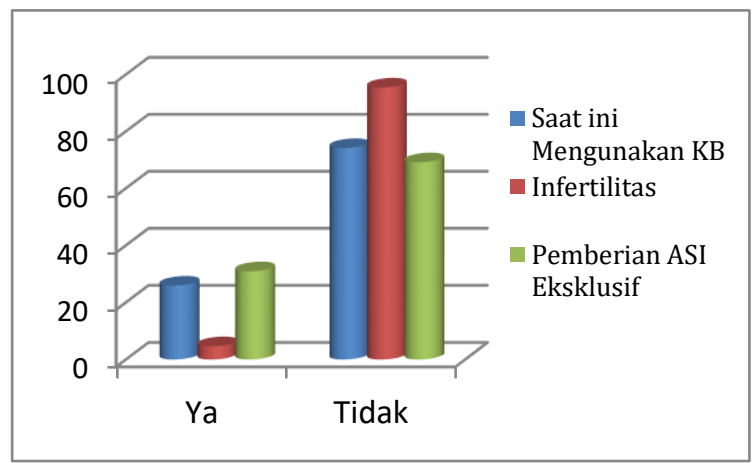

Responden yang mengalami infertilitas sangat kecil, hanya mencapai $4,62 \%$ dan yang tidak mengalami infertilitas mencapai 95,38\%. Responden yang memberikan ASI Eksklusif kepada anaknya mencapai $30,87 \%$ dan yang tidak memberikan ASI Eksklusif kepada anaknya mencapai $69,13 \%$.

\section{Hubungan Faktor-faktor Penentu}

Terdapat 12 faktor penentu yang digunakan untuk melihat hubungan masingmasing faktor tersebut dengan jumlah anak lahir hidup. Hasil analisis menunjukkan 12 faktor penentu tersebut memiliki hubungan yang signifikan dengan jumlah anak lahir hidup.

Proporsi wanita yang belum punya anak (0 anak), yang memiliki 1-2 anak lahir hidup, maupun yang memiliki lebih dari 2 anak lahir hidup terbesar terdapat pada wanita yang memiliki tingkat kesejahteraan menengah dibandingkan dengan wanita yang memiliki tingkat kesejahteraan rendah maupun tinggi. Hubungan antara tingkat kesejahteraan dengan jumlah anak lahir hidup dapat disimpulkan mempunyai hubungan yang signifikan. Ini ditunjukkan dengan nilai probabilitas yang dihasilkan sebesar 0,025 yang kurang dari $\alpha=0,05$.

Proporsi wanita yang memiliki 1-2 anak lahir hidup maupun lebih dari 2 anak lahir hidup cenderung menurun dengan semakin banyak jumlah anak yang meninggal. Diperlihatkan juga bahwa proporsi wanita yang memiliki lebih dari 2 anak lahir hidup labih banyak jika dibandingkan wanita yang memiliki 1-2 anak lahir hidup pada wanita yang yang mengalami kematian anak sebanyak 1 anak, 2 anak, dan 4 anak. Kondisi ini ditunjukkan dengan hubungan yang signifikan antara jumlah kematian anak dengan jumlah anak lahir hidup $(p=0,000<\alpha=0,05)$ tabel 1 . 
Marfin Lawalata, Jino Tehusalawane, Misco Tamaela, Marlon S. Noya van Delzen \& Felecia P. Adam, Analisa Faktor Yang Mempengaruhi Tingkat Fertilitas di Provinsi Maluku (Analisa Lanjutan Hasil SKAP 2019)

Tabel 1. Analisis Hubungan Variabel Indeks Kesejahteraan, Jumlah Anak yang Meninggal, Jumlah Anak yang Diinginkan dan Jumlah Anak Lahir Hidup yang Dimiliki, SKAP 2020 Faktor

\begin{tabular}{|c|c|c|c|c|c|c|c|}
\hline \multirow[b]{3}{*}{ Tingkat Kesejahteraan } & \multicolumn{6}{|c|}{ 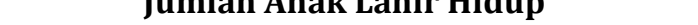 } & \multirow{3}{*}{$\begin{array}{c}\text { Nilai } \\
\text { Probabilitas }\end{array}$} \\
\hline & \multicolumn{2}{|c|}{0 Anak } & \multicolumn{2}{|c|}{1 - 2 Anak } & \multicolumn{2}{|c|}{$>2$ Anak } & \\
\hline & $\mathrm{N}$ & $\%$ & $\mathrm{n}$ & $\%$ & $\mathrm{n}$ & $\%$ & \\
\hline Rendah & 92 & 19,7 & 122 & 24,0 & 146 & 25,1 & 0,025 \\
\hline Menegah & 287 & 61,3 & 266 & 52,3 & 326 & 56,1 & \\
\hline Tinggi & 89 & 19,0 & 121 & 23,8 & 109 & 18,8 & \\
\hline \multicolumn{8}{|l|}{ Kematian Anak } \\
\hline 0 Anak & 463 & 98,9 & 461 & 90,6 & 520 & 89,5 & 0,000 \\
\hline 1 Anak & 4 & 0,9 & 34 & 6,7 & 38 & 6,5 & \\
\hline 2 Anak & 0 & 0,0 & 10 & 2,0 & 13 & 2,2 & \\
\hline 3 Anak & 1 & 0,2 & 3 & 0,6 & 3 & 0,5 & \\
\hline 4 Anak & 0 & 0,0 & 1 & 0,2 & 7 & 1,2 & \\
\hline \multicolumn{8}{|l|}{ Anak yang Diinginkan } \\
\hline$\leq 2$ Anak & 331 & 70,7 & 324 & 63,7 & 162 & 27,9 & 0,000 \\
\hline$>2$ Anak & 137 & 29,3 & 185 & 36,3 & 419 & 72,1 & \\
\hline
\end{tabular}

Sumber data : SKAP, 2019 Diolah

Tabel 2. Analisis Hubungan Variabel Terpapar Media Tentang KB, Kontak dengan Petugas KB dalam 6 Bulan Terakhir, Pendapat Suami terhadap KB dan Jumlah Anak Lahir Hidup yang Dimiliki, SDKI 2020.

\begin{tabular}{|c|c|c|c|c|c|c|c|}
\hline Faktor & \multicolumn{6}{|c|}{ Jumlah Anak Lahir Hidup } & \multirow{3}{*}{$\begin{array}{c}\text { Nilai } \\
\text { Probabilitas }\end{array}$} \\
\hline \multirow{2}{*}{ Terpapar Media Tentang KB } & \multicolumn{2}{|c|}{0 Anak } & \multicolumn{2}{|c|}{1 - 2 Anak } & \multicolumn{2}{|c|}{$>2$ Anak } & \\
\hline & $\mathrm{n}$ & $\%$ & $\mathrm{n}$ & $\%$ & $\mathrm{n}$ & $\%$ & \\
\hline Ya & 429 & 91,7 & 453 & 89,0 & 502 & 86,4 & 0,027 \\
\hline Tidak & 39 & 8,3 & 56 & 11,0 & 79 & 13,6 & \\
\hline \multicolumn{8}{|l|}{$\begin{array}{c}\text { Kontak dengan Petugas KB dalam } 12 \text { Bulan } \\
\text { Terakhir }\end{array}$} \\
\hline $\mathrm{Ya}$ & 47 & 10,0 & 101 & 19,8 & 123 & 21,2 & 0,000 \\
\hline Tidak & 421 & 90,0 & 408 & 80,2 & 458 & 78,8 & \\
\hline \multicolumn{8}{|l|}{ Pendapat Suami terhadap KB } \\
\hline Setuju & 1 & 0,2 & 161 & 31,6 & 207 & 35,6 & 0,000 \\
\hline Tidak Setuju & 0 & 0,0 & 4 & 0,8 & 27 & 4,6 & \\
\hline Tidak Tahu & 467 & 99,8 & 344 & 67,6 & 347 & 59,7 & \\
\hline
\end{tabular}

Sumber data : SKAP, 2019 Diolah

Proporsi wanita yang memiliki 1-2 anak lahir lebih banyak terpapar media tentang KB dibanding yang tidak terpapar media tentang KB. Hal yang sama juga berlaku untuk wanita yang memiliki lebih dari 2 anak, jumlah wanita yang terpapar media tentang KB lebih besar dibanding yang tidak terpapar media tentang KB. Hubungan antara kontak dengan petugas KB dalam 12 bulan terkahir dengan jumlah anak lahir hidup mempunyai hubungan yang signifikan. Ini ditunjukkan dengan nilai $p=0,000<\alpha=0,05$ Jumlah wanita yang memiliki 1-2 anak lahir hidup lebih sedikit dibanding jumlah wanita yang memiliki lebih dari 2 anak jika dilihat berdasarkan suami yang setuju maupun tidak setuju dengan KB. Kondisi ini ditunjukkan dengan hubungan yang signifikan antara pendapat suami terhadap KB dengan jumlah anak lahir hidup $(p=0,027<\alpha=0,05)^{\text {tabel } 2 .}$ 
Tabel 3. Analisis Hubungan Variabel Umur Melakukan Hubungan Seksual Pertama kali, Umur Melahirkan Anak Pertama dan Jumlah Anak Lahir Hidup yang Dimiliki, SKAP 2019

\begin{tabular}{|c|c|c|c|c|c|c|c|}
\hline \multirow{3}{*}{$\begin{array}{c}\text { Faktor } \\
\begin{array}{c}\text { Umur Pada Saat Hubungan Sex } \\
\text { Pertama }\end{array}\end{array}$} & \multicolumn{6}{|c|}{ Jumlah Anak Lahir Hidup } & \multirow{3}{*}{$\begin{array}{c}\text { Nilai } \\
\text { Probabilitas }\end{array}$} \\
\hline & \multicolumn{2}{|c|}{0 Anak } & \multicolumn{2}{|c|}{1 - 2 Anak } & \multicolumn{2}{|c|}{$>2$ Anak } & \\
\hline & $\mathrm{N}$ & $\%$ & $\mathrm{n}$ & $\%$ & $\mathrm{n}$ & $\%$ & \\
\hline Belum Pernah & 288 & 61,5 & 0 & 0,0 & 0 & 0,0 & 0,000 \\
\hline$<15$ Tahun & 3 & 0,6 & 10 & 2,0 & 13 & 2,2 & \\
\hline 15 - 19 Tahun & 35 & 7,5 & 153 & 30,1 & 221 & 38,0 & \\
\hline 20 - 24 Tahun & 50 & 10,7 & 209 & 41,1 & 213 & 36,7 & \\
\hline$\geq 25$ Tahun & 24 & 5,1 & 96 & 18,9 & 52 & 9,0 & \\
\hline Lupa & 68 & 14,5 & 41 & 8,1 & 82 & 14,1 & \\
\hline \multicolumn{8}{|l|}{ Umur Melahirkan Pertama } \\
\hline Belum Pernah & 467 & 99,8 & 220 & 43,2 & 1 & 0,2 & 0,000 \\
\hline 15 - 19 Tahun & 1 & 0,2 & 48 & 9,4 & 132 & 22,7 & \\
\hline 20 - 24 Tahun & 0 & 0,0 & 122 & 24,0 & 302 & 52,0 & \\
\hline 25 - 29 Tahun & 0 & 0,0 & 88 & 17,3 & 109 & 18,8 & \\
\hline$\geq 30$ Tahun & 0 & 0,0 & 31 & 6,1 & 37 & 6,4 & \\
\hline
\end{tabular}

Sumber data : SKAP, 2019 Diolah

Dengan nilai $p=0,000<\alpha=0,05$; maka hubungan antara umur pada saat hubungan sex pertama mempunyai hubungan yang signifikan dengan jumlah anak lahir hidup. Untuk wanita yang memiliki 1-2 anak lahir hidup lebih banyak dijumpai pada wanita yang pertama kali melahirkan pada umur 2024 tahun. Dengan nilai $p=0,000<\alpha=0,05$; maka hubungan antara umur melahirkan pertama mempunyai hubungan yang signifikan dengan jumlah anak lahir hidup (Tabel 3).

$$
\text { Dengan nilai } p=0,000<\alpha=0,05 \text {; }
$$

maka hubungan antara infertilitas mempunyai hubungan yang signifikan dengan jumlah anak lahir hidup. Dengan nilai $p=0,000<\alpha=0,05$; maka hubungan antara pemberian ASI Eksklusif mempunyai hubungan yang signifikan dengan jumlah anak lahir hidup. (Tabel 4).

Tabel 4. Analisis Hubungan Variabel Infertilitas, Pemberian ASI Eksklusif dan Jumlah Anak Lahir Hidup yang Dimiliki, SKAP 2019

\begin{tabular}{|c|c|c|c|c|c|c|c|}
\hline \multirow{3}{*}{$\begin{array}{c}\text { Faktor } \\
\text { Infertilitas }\end{array}$} & \multicolumn{6}{|c|}{ Jumlah Anak Lahir Hidup } & \multirow{3}{*}{$\begin{array}{c}\text { Nilai } \\
\text { Probabilitas }\end{array}$} \\
\hline & \multicolumn{2}{|c|}{0 Anak } & \multicolumn{2}{|c|}{ 1-2 Anak } & \multicolumn{2}{|c|}{$>2$ Anak } & \\
\hline & $\mathrm{n}$ & $\%$ & $\mathrm{n}$ & $\%$ & $\mathrm{n}$ & $\%$ & \\
\hline Ya & 46 & 9,8 & 11 & 2,2 & 15 & 2,6 & 0,000 \\
\hline Tidak & 422 & 90,2 & 498 & 97,8 & 566 & 97,4 & \\
\hline \multicolumn{8}{|l|}{ ASI Eksklusif } \\
\hline Ya & 101 & 21,6 & 163 & 32,0 & 217 & 37,3 & 0,000 \\
\hline Tidak & 367 & 78,4 & 346 & 68,0 & 364 & 62,7 & \\
\hline
\end{tabular}

Sumber data : SKAP, 2019 Diolah

Proporsi wanita yang memiliki 2 anak lahir hidup akan terus meningkat dari kelompok umur 15-19 tahun sampai dengan umur 25-29 tahun, dan akan terus menurun setelah kelompok umur tersebut. Sedangkan untuk proporsi wanita yang memiliki lebih dari 2 anak lahir hidup terus meningkat mulai dari kelompok umur 15-19 tahun sampai kelompok
40-44 tahun dan akan menurun setelah itu. Wanita yang memiliki 1-2 anak lahir hidup lebih banyak yang bertempat tinggal di wilayah pedesaan dibandingkan dengan wilayah perkotaan. Hal yang sama juga belaku untuk wanita yang memiliki lebih dari 2 anak lahir hidup (Tabel 5). 
Marfin Lawalata, Jino Tehusalawane, Misco Tamaela, Marlon S. Noya van Delzen \& Felecia P. Adam, Analisa Faktor Yang Mempengaruhi Tingkat Fertilitas di Provinsi Maluku (Analisa Lanjutan Hasil SKAP 2019)

Tabel 5. Analisis Hubungan Variabel Umur, Tempat tinggal dan Jumlah Anak Lahir Hidup yang Dimiliki, SKAP 2019

Faktor Jumlah Anak Lahir Hidup

\begin{tabular}{|c|c|c|c|c|c|c|c|}
\hline Faktor & \multicolumn{6}{|c|}{ Jumlah Anak Lahir Hidup } & \multirow[b]{2}{*}{ Nilai Probabilita } \\
\hline Umur Responden & \multicolumn{2}{|c|}{0 Anak } & \multicolumn{2}{|c|}{1 - 2 Anak } & \multicolumn{2}{|c|}{$>2$ Anak } & \\
\hline 15 - 19 Tahun & 216 & 46,2 & 13 & 2,6 & 1 & 1,2 & 0,000 \\
\hline 20 - 24 Tahun & 105 & 22,4 & 75 & 14,7 & 6 & , 0 & \\
\hline 25 - 29 Tahun & 77 & 16,5 & 105 & 20,6 & 37 & $i, 4$ & \\
\hline 30 - 34 Tahun & 25 & 5,3 & 100 & 19,6 & 110 & 3,9 & \\
\hline 35 - 39 Tahun & 26 & 5,6 & 87 & 17,1 & 153 & 6,3 & \\
\hline 40 - 44 Tahun & 10 & 2,1 & 67 & 13,2 & 165 & 3,4 & \\
\hline 45 - 49 Tahun & 9 & 1,9 & 62 & 12,2 & 109 & 3,8 & \\
\hline \multicolumn{8}{|c|}{ Wilayah Tempat Tinggal } \\
\hline Perkotaan & 205 & 43,8 & 157 & 30,8 & 163 & 3,1 & 0,000 \\
\hline Pedesaan & 263 & 56,2 & 352 & 69,2 & 418 & 1,9 & \\
\hline
\end{tabular}

Sumber data : SKAP, 2019 Diolah

\section{Interpretasi Faktor Dominan}

Setelah dilakukan signifikasi parameter uji serentak untuk mengetahui signifikan parameter tehadap variabel bebas, dan telah teruji memenuhi signifikan terhadap variabel terikat, ditemukan bahwa terdapat 1 variabel independen signifikan terhadap varibael terikat yang dapat menjelaskan status faktor yang mempengaruhi jumlah kelahiran anak. Tahap selanjutnya melakukan pengujian parsial. Pengujian parsial dilakukan untuk mengetahui seberapa banyak variabel independen yang berpengaruh terhadap kelahiran anak lahir hidup di Provinsi Maluku. Dan ditemukan terdapat 6 variabel yang signifikan, yaitu Umur Responden, Jumlah Kematian Anak, Jumlah Anak Ideal, Pendapatan Suami Terhadap KB, Umur Responden pada Saat Melakukan Hubungan Sex Pertama Kali, dan Umur Responden pada saat Melahirkan Anak Pertama Kali.

Tabel 6. Hasil Estimasi Parameter untuk Model Responden yang memiliki 1-2 Anak Lahir Hidup

\begin{tabular}{|c|c|c|c|c|c|c|c|}
\hline \multicolumn{2}{|c|}{ Anak Lahir Hidup ${ }^{a}$} & B & Std. Error & Wald & df & Sig. & $\operatorname{Exp}(B)$ \\
\hline \multirow[t]{29}{*}{1 - 2 Anak } & Intercept & 42,192 & 3728,756 & 0,000 & 1 & 0,991 & \\
\hline & Umur & $-0,004$ & 0,013 & 0,111 & 1 & 0,739 & 0,996 \\
\hline & {$[\mathrm{TK}=1,00]$} & $-0,161$ & 0,380 & 0,181 & 1 & 0,671 & 0,851 \\
\hline & {$[\mathrm{TK}=2,00]$} & $-0,172$ & 0,319 & 0,289 & 1 & 0,591 & 0,842 \\
\hline & {$[\mathrm{TK}=3,00]$} & $0^{\mathrm{b}}$ & & & 0 & & \\
\hline & {$[\mathrm{KA}=, 00]$} & 10,422 & 3650,316 & 0,000 & 1 & 0,998 & 33573,902 \\
\hline & {$[\mathrm{KA}=1,00]$} & $-2,916$ & 3638,980 & 0,000 & 1 & 0,999 & 0,054 \\
\hline & {$[\mathrm{KA}=2,00]$} & $-1,125$ & 4000,010 & 0,000 & 1 & 1,000 & 0,325 \\
\hline & {$[\mathrm{KA}=3,00]$} & $-16,208$ & 3628,014 & 0,000 & 1 & 0,996 & $9,143 \mathrm{E}-8$ \\
\hline & {$[\mathrm{KA}=4,00]$} & $0^{\mathrm{b}}$ & & & 0 & & \\
\hline & {$[\mathrm{AI}=1,00]$} & $-0,126$ & 0,270 & 0,220 & 1 & 0,639 & 0,881 \\
\hline & {$[\mathrm{AI}=2,00]$} & $0^{\mathrm{b}}$ & & & 0 & & \\
\hline & {$[$ Media=,00] } & 0,063 & 0,407 & 0,024 & 1 & 0,877 & 1,065 \\
\hline & {$[$ Media $=1,00]$} & $0^{\mathrm{b}}$ & & & 0 & & \\
\hline & {$[$ Kontak=,00] } & $-0,560$ & 0,328 & 2,909 & 1 & 0,088 & 0,571 \\
\hline & {$[$ Kontak $=1,00]$} & $0^{\mathrm{b}}$ & & & 0 & & \\
\hline & {$[\mathrm{PSTKB}=, 00]$} & $-13,992$ & 1,240 & 127,372 & 1 & 0,000 & 8,379E-7 \\
\hline & {$[\mathrm{PSTKB}=1,00]$} & $-9,662$ & 0,682 & 200,867 & 1 & 0,000 & $6,366 \mathrm{E}-5$ \\
\hline & {$[\mathrm{PSTKB}=2,00]$} & $0^{\mathrm{b}}$ & & & 0 & & \\
\hline & {$[\mathrm{UHSP}=1,00]$} & $-17,652$ & 922,643 & 0,000 & 1 & 0,985 & $2,158 \mathrm{E}-8$ \\
\hline & {$[\mathrm{UHSP}=2,00]$} & 1,195 & 0,980 & 1,486 & 1 & 0,223 & 3,303 \\
\hline & {$[\mathrm{UHSP}=3,00]$} & 1,897 & 0,395 & 23,098 & 1 & 0,000 & 6,666 \\
\hline & {$[\mathrm{UHSP}=4,00]$} & 1,854 & 0,378 & 24,098 & 1 & 0,000 & 6,382 \\
\hline & {$[\mathrm{UHSP}=5,00]$} & 2,168 & 0,428 & 25,710 & 1 & 0,000 & 8,745 \\
\hline & {$[\mathrm{UHSP}=6,00]$} & $0^{\mathrm{b}}$ & & & 0 & & \\
\hline & {$[\mathrm{UMP}=, 00]$} & $-39,343$ & 952,758 & 0,002 & 1 & 0,967 & 8,193E-18 \\
\hline & {$[\mathrm{UMP}=1,00]$} & $-12,788$ & 860,890 & 0,000 & 1 & 0,988 & $2,795 \mathrm{E}-6$ \\
\hline & {$[\mathrm{UMP}=2,00]$} & $-1,327$ & 927,984 & 0,000 & 1 & 0,999 & 0,265 \\
\hline & {$[\mathrm{UMP}=3,00]$} & $-11,479$ & 1070,253 & 0,000 & 1 & 0,991 & $1,035 \mathrm{E}-5$ \\
\hline
\end{tabular}




\begin{tabular}{|c|c|c|c|c|c|c|c|}
\hline \multirow{6}{*}{} & {$[\mathrm{UMP}=4,00]$} & $0^{\mathrm{b}}$ & & & 0 & & \\
\cline { 2 - 8 } & {$[$ Infertilitas=1,00] } & $-0,865$ & 0,534 & 2,626 & 1 & 0,105 & 0,421 \\
\cline { 2 - 8 } & {$[$ Infertilitas=2,00] } & $0^{\mathrm{b}}$ & & & 0 & & \\
\cline { 2 - 8 } & {$[$ ASI $=1,00]$} & $-0,154$ & 0,268 & 0,331 & 1 & 0,565 & 0,857 \\
\cline { 2 - 8 } & {$[\mathrm{ASI}=2,00]$} & $0^{\mathrm{b}}$ & & & 0 & & \\
\cline { 2 - 8 } & {$[\mathrm{TT}=1,00]$} & $-0,156$ & 0,267 & 0,341 & 1 & 0,559 & 0,856 \\
\cline { 2 - 8 } & {$[\mathrm{TT}=2,00]$} & $0^{\mathrm{b}}$ & & 0 & & \\
\hline
\end{tabular}

Sumber data : SKAP, 2019 Diolah

Berikut adalah pengaruh variabelvariabel bebas yang signifikan terhadap jumlah anak lahir hidup sebanyak 1-2 anak dengan tujuan untuk menggambarkan seberapa besarnya kecendrungan variabel sebagai hasil tertentu yang muncul dengan diinterpretasikan sebagai berikut :

1. Variabel umur memiliki nilai Exp (B) sebesar 0,996; ini artinya semakin bertambahnya umur responden dan ketika belum mencapai umur 50 tahun, maka responden tersebut cenderung memiliki 12 anak lahir hidup sebesar 0,996 kali lipat dari responden yang tidak memiliki anak lahir hidup.

2. Variabel tingkat kesejahteraan rendah dengan nilai Exp (B) sebesar 0,851. Dari nilai tersebut dapat diartikan bahwa, semakin rendah tingkat kesejahteraan sesorang, maka wanita yang pernah melahirkan cendrung memiliki 1-2 anak lahir hidup sebesar 0,851 kali lipat dari responden yang tidak memiliki anak lahir hidup.

3. Variabel tingkat kematian anak. Untuk responden yang tidak pernah mengalami kematian anak memiliki nilai Exp (B) sebesar 33573,902; ini berarti responden yang tidak pernah mengalami kematian anak cenderung mempunyai 1-2 anak lahir hidup daripada tidak memiliki anak lahir hidup sebesar 33573,902 kali lipat dari responden yang pernah mengalami 4 kematian anak

Variabel jumlah anak yang diinginkan. Responden yang mengiginkan 2 anak atau kurang mempunyai nilai Exp (B) sebesar 0,881 . Ini dapat diartikan bahwa responden yang menginginkan 2 anak atau kurang cenderung mempunyai 1-2 anak lahir hidup daripada tidak memiliki anak lahir hidup sebesar 0,881 kali lipat dari responden yang menginginkan lebih dari 2 anak.

1. Variabel keterpaparan media. Responden yang mendapat keterpaparan media mempunyai nilai Exp (B) sebesar 1,065. Ini diartikan sebagai responden yang mendapat keterpaparan media cendrung memiliki anak 1-2 orang anak lahir hidup sebesar 1,065 daripada tidak mendapatkan keterpaparan media.

2. Variabel pendapat suami tentang KP. Bagi responden yang tidak mengetahui pendapat suami tentang KB memiliki nilai Exp (B) sebesar 8,379X10-7. Ini diartikan sebagai responden yang tdak mengetahui pendapat suami tentang $\mathrm{KB}$ cenderung memiliki 1-2 anak lahir hidup daripada tidak memiliki anak lahir hidup sebesar $8,379 \times 10^{-7}$ kali lipat dari responden yang suaminya tidak setuju terhadap KB

3. Variabel umur hubungan sex pertama nilai Exp (B) terbesar terdapat pada responden yang melakukan hubungan sex pertama kali pada umur 25 tahun atau lebih, yaitu sebesar 8,745. Nilai ini bermakna, responden yang melakukan hubungan sex pertama kali pada umur 25 tahun atau lebih cenderung memiliki 1-2 anak lahir hidup daripada tidak memiliki anak lahir hidup sebesar 8,745 kali dibanding responden yang telah lupa kapan pertama kali melakukan hubunga sex.

Variabel umur menikah pertama. Bagi variabel umur responden saat melahirkan pertama nilai Exp (B) terbesar terdapat pada responden yang berumur 20-24 tahun, yaitu sebesar 0,265. Ini berarti responden yang berumur 20-24 tahun saat melahirkan pertama kali akan cenderung memiliki 1-2 anak lahir hidup daripada tidak memilki anak lahir hidup sebesar 0,265 kali lipat dibanding responden yang melahirkan pertama kali pada umur 30 tahun atau lebih.

Berikut adalah pengaruh variabelvariabel bebas yang signifikan terhadap jumlah anak lahir hidup sebanyak lebih dari 2 anak lahir hidup dengan tujuan untuk menggambarkan seberapa besarnya kecendrungan variabel sebagai hasil tertentu yang muncul dengan diinterpretasikan sebagai berikut : 
Marfin Lawalata, Jino Tehusalawane, Misco Tamaela, Marlon S. Noya van Delzen \& Felecia P. Adam, Analisa Faktor Yang Mempengaruhi Tingkat Fertilitas di Provinsi Maluku (Analisa Lanjutan Hasil SKAP 2019)

1. Variabel umur memiliki nilai Exp (B) sebesar 1,020; ini berarti semakin bertambahnya umur responden dan ketika belum mencapai umur 50 tahun, maka responden tersebut cenderung memiliki lebih dari 2 anak lahir hidup sebesar 1,020 kali lipat dari responden yang tidak memiliki anak lahir hidup.

2. Variabel kematian anak. Untuk responden yang tidak pernah mengalami kematian anak memiliki nilai Exp (B) sebesar 8974,418; ini berarti responden yang tidak pernah mengalami kematian anak cenderung mempunyai lebih dari 2 anak lahir hidup daripada tidak memiliki anak lahir hidup sebesar 8974,418 kali lipat dari responden yang pernah mengalami 4 kematian anak.

3. Variabel jumlah anak yang diinginkan. Responden yang mengiginkan 2 anak atau kurang mempunyai nilai Exp (B) sebesar 0,159 . Ini dapat diartikan bahwa responden yang menginginkan 2 anak atau kurang cenderung mempunyai lebih dari 2 anak lahir hidup daripada tidak memiliki anak lahir hidup sebesar 0,159 kali lipat dari responden yang menginginkan lebih dari 2 anak.

4. Variabel pendapat suami tentang KB. Bagi responden yang tidak mengetahui pendapat suami tentang KB memiliki nilai Exp (B) sebesar 1,393X10-7. Ini diartikan sebagai responden yang tdak mengetahui pendapat suami tentang $\mathrm{KB}$ cenderung memiliki lebih dari 2 anak lahir hidup daripada tidak meiliki anak lahir hidup sebesar 1,393X10 $0^{-7}$ kali lipat dari responden yang suaminya tidak setuju terhadap KB

5. Variabel umur hubungan sex pertama. Bagi variabel umur hubungan sex pertama nilai Exp (B) terbesar terdapat pada responden yang melakukan hubungan sex pertama kali pada umur 15-19 tahun, yaitu sebesar 4,081 . Nilai ini bermakna, responden yang melakukan hubungan sex pertama kali pada umur 15-19 tahun cenderung memiliki lebih dari 2 anak lahir hidup daripada tidak memiliki anak lahir hidup sebesar 4,081 kali dibanding responden yang telah lupa kapan pertama kali melakukan hubunga sex.

Bagi variabel umur responden saat melahirkan pertama nilai Exp (B) terbesar terdapat pada responden yang berumur 20-24 tahun, yaitu sebesar 0,614. Ini berarti responden yang berumur 20-24 tahun saat melahirkan pertama kali akan cenderung memiliki lebih dari 2 anak lahir hidup daripada tidak memilki anak lahir hidup sebesar 0,614 kali lipat dibanding responden yang melahirkan pertama kali pada umur 30 tahun atau lebih.

Variabel ASI. Pemberian asi memiliki nilai Exp (B) sebesar 1,285. Ini berarti responden yang tidak memberikan ASI cendrung memiliki lebih dari 2 anak lahir hidup daripada tidak memiliki anak lahir hidup sebesar 1,285 kali lipat dari responden yang memberikan ASI ekslusif. 
Tabel 7. Estimasi Parameter untuk Model Responden yang memilikiLebih dari 2 Anak Lahir Hidup

\begin{tabular}{|c|c|c|c|c|c|c|c|}
\hline \multicolumn{2}{|c|}{ Anak Lahir Hidup ${ }^{a}$} & $\mathrm{~B}$ & Std. Error & Wald & Df & Sig. & $\operatorname{Exp}(B)$ \\
\hline \multirow{2}{*}{$\begin{array}{c}> \\
\text { Anak }\end{array}$} & 2 Intercept & 45,726 & 3728,756 & 0,000 & 1 & 0,990 & \\
\hline & Umur & 0,020 & 0,016 & 1,564 & 1 & 0,211 & 1,020 \\
\hline & {$[\mathrm{TK}=1,00]$} & $-0,397$ & 0,456 & 0,760 & 1 & 0,383 & 0,672 \\
\hline & {$[\mathrm{TK}=\mathbf{2 , 0 0 ]}$} & $-0,022$ & 0,387 & 0,003 & 1 & 0,955 & 0,978 \\
\hline & {$[\mathrm{TK}=3,00]$} & $\mathrm{o}^{\mathrm{b}}$ & & & o & & \\
\hline & {$[\mathrm{KA}=, \mathrm{oo}]$} & 90,099 & 3650,316 & 0,000 & 1 & 0,998 & 8947,418 \\
\hline & {$[\mathrm{KA}=1, \mathrm{Oo}]$} & $-5,329$ & 3638,980 & 0,000 & 1 & 0,999 & 0,005 \\
\hline & {$[\mathrm{KA}=\mathbf{2}, \mathrm{0o}]$} & $-3,621$ & 4000,010 & 0,000 & 1 & 0,999 & 0,027 \\
\hline & {$[\mathrm{KA}=3,00]$} & $-19,065$ & 3628,014 & 0,000 & 1 & 0,996 & $5,249 \mathrm{E}-9$ \\
\hline & {$[\mathrm{KA}=4, \mathrm{oo}]$} & $\mathrm{o}^{\mathrm{b}}$ & & & o & & \\
\hline & {$[\mathrm{AI}=1,00]$} & $-1,839$ & 0,320 & 33,040 & 1 & 0,000 & 0,159 \\
\hline & {$[\mathrm{AI}=\mathbf{2 , 0 0}]$} & $\mathrm{o}^{\mathrm{b}}$ & & & o & & \\
\hline & {$[$ Media=,oo] } & 0,117 & 0,480 & 0,059 & 1 & 0,808 & 1,124 \\
\hline & {$[$ Media=1,oo] } & $\mathrm{o}^{\mathrm{b}}$ & & & o & & \\
\hline & {$[$ Kontak=,oo] } & $-0,640$ & 0,385 & 2,770 & 1 & 0,096 & 0,527 \\
\hline & {$[$ Kontak=1,oo] } & $\mathrm{o}^{\mathrm{b}}$ & & & o & & \\
\hline & {$[\mathrm{PSTKB}=, \mathrm{oo}]$} & $-15,787$ & 1,049 & 226,298 & 1 & 0,000 & $1,393 \mathrm{E}-7$ \\
\hline & {$[\mathrm{PSTKB}=1,00]$} & $-11,238$ & 0,000 & & 1 & & $1,316 \mathrm{E}-5$ \\
\hline & {$[\mathrm{PSTKB}=\mathbf{2 , 0 0}]$} & $\mathrm{o}^{\mathrm{b}}$ & & & o & & \\
\hline & {$[\mathrm{UHSP}=1, \mathrm{oo}]$} & $-12,346$ & 848,112 & 0,000 & 1 & 0,988 & $4,347 \mathrm{E}-6$ \\
\hline & {$[\mathrm{UHSP}=\mathbf{2 , 0 0}]$} & 0,207 & 1,158 & 0,032 & 1 & 0,858 & 1,230 \\
\hline & {$[\mathrm{UHSP}=3,00]$} & 1,406 & 0,500 & 7,904 & 1 & 0,005 & 4,081 \\
\hline & {$[\mathrm{UHSP}=4,00]$} & 1,184 & 0,482 & 6,045 & 1 & 0,014 & 3,268 \\
\hline & {$[\mathrm{UHSP}=5, \mathrm{oo}]$} & 1,339 & 0,564 & 5,632 & 1 & 0,018 & 3,816 \\
\hline & {$[\mathrm{UHSP}=6,00]$} & $\mathrm{o}^{\mathrm{b}}$ & & & o & & \\
\hline & {$[\mathrm{UMP}=, \mathrm{oo}]$} & $-44,891$ & 952,759 & 0,002 & 1 & 0,962 & $3,192 \mathrm{E}-20$ \\
\hline & {$[\mathrm{UMP}=1,00]$} & $-11,930$ & 860,890 & 0,000 & 1 & 0,989 & $6,592 \mathrm{E}-6$ \\
\hline & {$[\mathrm{UMP}=\mathbf{2}, \mathbf{0 0}]$} & $-0,488$ & 927,985 & 0,000 & 1 & 1,000 & 0,614 \\
\hline & {$[\mathrm{UMP}=3,00]$} & $-11,329$ & 1070,253 & 0,000 & 1 & 0,992 & $1,202 \mathrm{E}-5$ \\
\hline & {$[\mathrm{UMP}=4,00]$} & $\mathrm{o}^{\mathrm{b}}$ & & & o & & \\
\hline & {$[$ Infertilitas $=\mathbf{1 , 0 0 ]}$} & $-0,298$ & 0,789 & 0,142 & 1 & 0,706 & 0,743 \\
\hline & {$[$ Infertilitas $=\mathbf{2 , 0 0 ]}$} & $\mathrm{o}^{\mathrm{b}}$ & & & o & & \\
\hline & {$[\mathrm{ASI}=1,00]$} & 0,251 & 0,320 & 0,613 & 1 & 0,434 & 1,285 \\
\hline & {$[\mathrm{ASI}=\mathbf{2 , 0 0}$} & $\mathrm{o}^{\mathrm{b}}$ & & & o & & \\
\hline & {$[\mathrm{TT}=1,00]$} & $-0,010$ & 0,323 & 0,001 & 1 & 0,975 & 0,990 \\
\hline & {$[\mathrm{TT}=\mathbf{2 , 0 0 ]}$} & $\mathrm{o}^{\mathrm{b}}$ & & & $\mathbf{O}$ & & \\
\hline
\end{tabular}

Sumber data : SKAP, 2019 Diolah 
Marfin Lawalata, Jino Tehusalawane, Misco Tamaela, Marlon S. Noya van Delzen \& Felecia P. Adam, Analisa Faktor Yang Mempengaruhi Tingkat Fertilitas di Provinsi Maluku (Analisa Lanjutan Hasil SKAP

2019)

\section{Hubungan Antara Faktor Demografi dan Fertilias}

Hasil penelitian menunjukan bahwa umur juga berhubungan dengan umur pertama kali melahirkan, wanita yang memiliki umur lebih tua biasanya umur kawin pertamanya jauh lebih muda. Karena sesungguhnya umur kawin petama juga berpengaruh kuat terhadap struktur demografi, sosial, dan yang berimbas keadaan ekonomi keluarga yang juga rendah. Justru, sebaliknya wanita yang memiliki umur lebih muda pada umumnya cendrung memiliki jumlah anak yang lebih sedikit dikarenakan umur pertama kawin yang lebih tinggi, dengan demikian hal ini akan berdampak juga terhadap tingkat ekonomi keluarga (Lennaria, 2017).

Umur kawin pertama adalah salah satu variabel penting, artinya semakin muda seorang perempuan memutuskan untuk menikah di usia dini, maka akan mengalami masa reproduksi yang tinggi karena adanya selang waktu yang panjang antara usia pubertas dan usia tidak subur, sehingga sangat besar kemungkinan dapat terjadi kehamilan dan melahirkan lebih dari satu anak (Ashani, 2015). Hal ini ditunjukan dari hasil penelitian yang dilakukan oleh Tisen, 2019 bahwa presentase tertinggi usia subur (PUS) di Gorontalo umur kawin pertama adalah 15-19 tahun sebesar 45\%, diikuti usia 25-29 tahun sebesar $12,1 \%$. Dengan hasil SKAP yang menunjukan usia umur kawin pertama masih tinggi dengan rentan umur 20-24 tahun, maka adanya berbagai upaya pemerintah untuk mendewasakan usia kawin pertama yang telah digencar saat ini. Hal ini perlu dilakukan Karena rentang usia produktif yang sangat lama akan berpeluang besar melahirkan anak sangat tinggi.

Indikator faktor demografi lain yang mempengaruhi tingginya TFR adalah wilayah tempat tinggal responden. Penelitian dari Islamuddin,dkk (2011) menyebutkan bahwa, wanita di pedesaan mempunyai banyak anak dibandingkan dengan wanita yang tinggal di perkotaan, sesuai dengan analisis hasil bahwa hubungan tempat tinggal terhadap variabel jumlah anak lahir hidup mempunyai pengaruh signifikan dan hubungan yang bermakna. Hal ini bisa disebabkan oleh adanya faktor akses sarana prasarana fasilitas kesehatan yang sudah menunjang serta pandangan keluarga tentang banyaknya anak sebagai faktor produksi tenaga kerjaa yang bersumber dari dalam keluarga yang dapat menunjang pekerjaan keluarga untuk bertani atau berkebun pada daerah pedesaan yang notabennya adalah masyarakat dengan mata pencharian sebagai petani. Prespektif masyarakat desa meyakinkan bahwa, dengan memiliki jumlah anak yang banyak orang tua bisa memperoleh keuntungan jika anak-anak tersebut bekerja. Hal ini relevan jika dikaji berdasarkan teori ekonomi, yang berhubungan dengan fertilitas kehadiran anak sebagai uilitas dan juga dari segi ekonomi menguntungkan (Saputro, 2009). Kemudian hal ini juga sesuai dengan penelitian yang diungkapkan oleh Becker (1960) dalam Arsyad (2016) ketika anak dilihat sebagai aspek produksi jadi utilitas anak yang menjadi faktor dominan adalah kuantitas anak bukan berdasarkan kualitas anak.

\section{Faktor Sosial dan Ekonomi}

Indikator selanjutnya dikaji berdasarkan tingkat kesejahteraan. Teori Freedman (1975) dalam Arsyad (2016) yang memberikan model pengaruh faktor sosial dan ekonomi terhadap fertilitas yang dilihat berdasarkan, tingkat kesejahteraan dalam hal ini dikaji berdasarkan kuintil kekayaan dan jumlah anak meninggal. Berdasarkan hasil analisis hubungan antara tingkat kesejahteraan dengan jumlah anak lahir hidup diperoleh adanya hubungan yang signifikan, ditunjukkan dengan nilai probabilitas yang dihasilkan sebesar 0,025 < dari $\alpha=0,05$. Maka dapat disimpulkan bahwa jika tingkat kesejahteraan sesorang akan mempengaruhi jumlah anak lahir, biasanya masyarakat yang terdiri dari status ekonomi dengan golongan kebawah lebih tinggi jumlah fertilitasnya dibandingkan dengan masyarakat dengan status ekonomi menengah keatas.

Dilihat dari indikator jumlah anak yang diinginkan sebanyak $>2$ anak, berpengaruh signifikan terhadap tingginya TFR yaitu sebanyak $72 \%$. Hal iini disebabkan bahagaimana prespektif orangtua tentang keberlanjutan keturunan dan generasi di masa yang datang, kesehatan reproduksi ibu dan kondisi perekonomian keluarga. Karena pada dasarnya wanita yang memiliki usia kawin muda kesempatan unutk memiliki anak yang ideal juga semakin tinggi. Jumlah anak ideal yang diiingikan juga berkaitan dengan pengetahuan 
dan pemakaian kontrasepsi (Triana dan Wilopo, 2007)

Selanjutnya dilihat dari hasil penelitian menunjukan bahwa proporsi wanita yang memiliki lebih dari 2 anak lahir hidup lebih banyak jika dibandingkan wanita yang memiliki 1-2 anak lahir hidup pada wanita yang mengalami kematian anak sebanyak 1 anak, 2 anak, dan 4 anak. Kondisi yang signifikan antara jumlah kematian anak dengan jumlah anak lahir hidup $(p=0,000<\alpha=0,05)$. Hal ini sesuai dengan penelitian (Irawan, 2004), bahwa banyaknya anak yang meninggal maka, semakin banyak pula upaya suatu keluarga untuk menggantikan anak yang telah meninggal. Hal ini relevan berdasarkan teori dari Palloni dan Rafalimanana (1997) dalam Arsyad (2016) bahwa, adanya pengaruh kematian bayi terhadap fertilitas, dimana psikologi keluarga ketika seorang anak/bayi mereka meninggal maka harusnya digantikan dengan kehamilan kembali.

Keluarga yang memiliki tingkat ekonomi yang menengah akan cendrung untuk memikirkan kualitas anak ketimbang kuantitas anak termasuk kualitas pendidikan dan masa depan yang lebih baik, dengan demikian keluarga akan terfokus untuk meningkatkan kualitas anak itu. Sebaliknya juga dengan keluarga ekonomi dibawah yang cendrung melihat kehadiran anak sebagai aset investasi masa depan sehingga bebas menentukan jumlah ideal anak yang diinginkan (Sari, 2017).

Akses terhadap informasi sangat penting untuk menambah pengetahuan serta berpengaruh terhadap sikap dan perilaku seseorang (Sari, 2017). Hasil temuan oleh Adhikari (2010), menyatakan bahwa pengetahuan tentang penggunaan alat kontarsepsi modern berpengaruh signifikan terhadap jumlah kelahiran anak hidup, wanita yang memiliki pengetahuan lebih rendah tentang metode kontrasepsi berpeluang menghasilkan banyak anak, dibandingkan dengan wanita yang berpengetahuan tinggi, artinya semakin banyak metode kontrsepsi yang diketahui maka peluang wanita Ber-KB semakin tinggi pula dengan menyesuaikan pada kebutuhan WUS.

Umur pertama kali melahirkan merupakan variabel yang mempunyai pengaruh signifikan terhadap jumlah anak lahir hidup. Wanita yang baru melahirkan pertama pada dasarnya merupakan usia yang masih dalam pematangan reproduksi sehingga untuk kemungkinan untuk memiliki anak atau melahirkan kembali terulang dalam periode masa subur WUS.

Variabel berikut yaitu pemberian ASI Eksklusif pada hasil penelitian diperoleh nilai $p=0,000<\alpha=0,05$; maka hubungan antara pemberian ASI Eksklusif mempunyai hubungan yang signifikan dengan jumlah anak lahir hidup. Pemberian asi eklusif selama 6 bulan bagi anak usia 0 bulan harus memenuhi kriteria ibu dan bayi sehat. Faktor ini dapat merangsang efek hormonal yang mengatur adanya fertilisasi terhadap ibu dengan demikian akan memperkecil terjadinya konsepsi. Berdasarkan teori menyusui, setelah melahirkan untuk dapat melindungi wanita dari kehamilan kembali maka melalui periode lamanya amenore (kembali haid). Semakin sering pemberian ASI eklusif terhadap bayi tanpa pemberian makanan pendamping lainnya, maka akan semakin memperlama amenore ibu yang berdampak terhadap kelahiran kembali (Rohma. M, \& Andariya. D, 2021).

Pada umumnya masayarakat tidak akan tahu bahwa dengan menyusui, seorang wanita subur akan terhindar dari kehamilan, kegiatan pemberian ASI tidak akan mempengaruhi jumlah anak yang dimiliki oleh keluarga. Namun upaya untuk mengatasi terjadinya kehamilan kembali dapat dicegah pada ibu postpartum dengan frekuensi serta lamanya menyusui atau Amenorhea laktasi.

\section{SIMPULAN}

Berdasarkan hasil analisis terhadap 12 faktor langsung maupun faktor penentu yang paling berpengaruh terhadap jumlah anak hidup maka diperoleh adanya makna dan pengaruh yang signifikan antara 12 variabel dominan terhadap jumlah anak lahir hidup (nilai $\mathrm{p}=0,000$ ) yang meliputi faktor demografi (umur,tempat tinggal, dll) faktor sosial ekonomi (tingkat kesejahteraan, jumlah anak yang meninggal ,dll) serta pengaruh faktor lingkungan seperti keterpaparan terhadap media tentang $\mathrm{KB}$, kontak dengan petugas $\mathrm{KB}$, dll.

Ditemukan berdasarkan hasil analisis bivariat, bahwa faktor yang paling dominan yang mempengaruhi secara signifikan terjadinya jumlah angka kelahiran anak hidup adalalah jumlah anak yang meninggal,jumlah 
Marfin Lawalata, Jino Tehusalawane, Misco Tamaela, Marlon S. Noya van Delzen \& Felecia P. Adam, Analisa Faktor Yang Mempengaruhi Tingkat Fertilitas di Provinsi Maluku (Analisa Lanjutan Hasil SKAP 2019)

anak yang diinginkan, kontak dengan petugas $\mathrm{KB}$, pendapat suami terhadap $\mathrm{KB}$, usia hubungan intim pertama, usia pertama kali melahirkan, infertilitas, ASI eksklusif, umur, tempat tinggal, serta diikuti dengan faktor penentu keterpaparan media KB $(p=0,027)$ dan tingkat kesejehteraan $(\mathrm{p}=0,025)$.

Uji koefisien determinasi yang diperoleh adalah 0,825 atau $82,5 \%$. Ini berarti keragaman variabel variabel bebas mampu menjelaskan keragaman variabel jumlah anak lahir hidup sebesar 82,5\%. Sedangkan sisanya sebesar $17,5 \%$ dijelaskan oleh variabel lain yang tidak disertakan dalam model. Nilai estimasi parameter untuk model responden yang memiliki 1-2 anak atau > 2 anak lahir anak memiliki nilai Exp (B) sebesar 9,143X10-. Dengan demikian maka faktor sosial ekonomi yang berkontribusi penyebab tingginya jumlah kelahiran anak hidup di Provinsi Maluku adalah dari variabel jumlah anak meninggal terhadap keluarga yang pernah mengalami kematian anak.

\section{DAFTAR PUSTAKA}

Adhikari, R. (2010). Demografi, social economic, and cultural factors affecting fertility differentials in Nepal. BMC Pregnancy and Childbirth, 10(1). https://doi.org/10.1186/1471-2393$\underline{12-20 .}$

Ashani, T. A, \& Rofi, A (2012). Kematian Bayi, menurut Karakteristik Demografi dan Sosial Ekonomi Rumah tangga di Provinisi Jawa Barat. Jurnal : Bumi Indonesia. Vol 1(3).

Arsyad, S. S, \& Nurhayati, S. (2016). "Determinan Fertilitas di Indonesia". Jurnal Kependudukan Indonesia. 11(1): 1-14.

Irawan, T.I. (2004). Faktor Penentu Fertilitas. Analisis lanjut SDKI 2002-2003. Pusat Penelitian dan Pengembangan Keluarga Berencana dan Kesehatan Reproduksi,BKKBN. Jakarta.
Islamuddin, M.D., \& Bhuyan, K.C., (2011). Determinants of desired family size and children ever born in Bangladesh. The Journal of Family Welfare, 57(2), 39-47.

Mantra, I.B. (2003). Demografi Umum. Jakarta : Pustaka Raja.

Najib, \& Handayani, A. (2019). Keinginan memiliki anak berdasarkan teori pilihan Rasional (Analisis Data SDKI tahun 2017). Jurnal : Empati, 6 (2)

Rakhmatullah. A. (2015). Makalah Fertilitas. Https://ml.scribd.com/doc/246027969/ma kalah-fertilitas . Di akses 12 Febuari 2020.

Rohma. M \& Andariya. D, (2021). Analisis Durasi Menyusui Dengan Lama Amenorrhea Laktasi pada Ibu Postpartum. Jurnal : Oksitosin : Ilmu Kebidanan. 8(1).

Sari, N. (2017), Eterminan Fertilitas Melalui Pendekatan Total Fertility Rate (TFR) di Indonesia: Analisis Data Survei Demografi Kesehatan Indonesia (SDKI). Jurnal : DUNIA KESMAS. 6 (2)

Saputro, D. Determinan Keinginan Menambah Anak Di Propinsi Kepulauan Bangka Belitung (Analisis Data SDKI 2007). Jakarta: 2009.

SDKI. (2017). Survei demografi dan kesehatan Indonesia. Jakarta.

Sinaga. L., Hardiani, \& Prihanto. P. (2017). "FaktorFaktor Yang Mempengaruhi Tingginya Fertilitas di Pedesaan (Studi Pada Desa Pelayangan Kecamatan Muara Tembesi Kabupaten Batanghari)". Jurnal : Paradigma Ekonomi. 12 (I) : 41-48.

Suartha N. (2016). "Faktor-Faktor Yang Mempengaruhi Tingginya Laju Pertumbuhan Dan Implementasi Kebijakan Penduduk Di Provinsi Bali" Jurnal : PIRAMIDA Jurnal Kependudukan dan Pengembangan Sumber Daya Manusia. 12 (01): 1-7.

Triana, V. \& Wilopo, S.A. 2007. Pada Wanita Unmet need Kontrasepsi Di Indonesia (Analisis Data SDKI2007). 2007: 28-35. 